\title{
Pulmonary alveolar microlithiasis: review of Turkish reports
}

\author{
E S Ucan, A I Keyf, R Aydilek, Z Yalcin, S Sebit, M Kudu, U Ok
}

Gülhane Military
Medical Faculty,
Haydarpasa Training
Hospital
Department of Chest
Diseases, Medical
School, Dokuz Eylül
University, Izmir,
Turkey
E S Ucan
A I Keyf
R Aydilek
Z Yalcin
S Sebit
M Kudu
U Ok
Reprint requests to:
DrE S Ucan,
Türkay Cad.No 33,
Bornova, Izmir, Turkey
Received 28 February 1992
Returned to authors
1 April 1992
Revised version received
26 May 1992
Accepted 9 July 1992

Gülhane Military Haydarpasa Training

School, Dokuz Eylui

University, Izmir,

A I Keyf

R Aydilek

Dr E S Ucan,

Received 28 February 1992

Returned to authors

Accepted 9 July 1992

\begin{abstract}
Pulmonary alveolar microlithiasis is a rare disorder, only 173 cases having been reported worldwide. Fifty two cases from Turkey are reported, 49 of which have previously been described only in Turkish publications. The mean age of the patients was 27 (SD 12) years, 34 were male, and 10 were symptomless. In 40 of the 52 cases diagnosis was confirmed histopathologically. Nineteen cases were diagnosed in siblings. This high rate suggests that pulmonary alveolar microlithiasis is a familial disease, which, though rare, is for unknown reasons most common in Turkey.
\end{abstract}

(Thorax 1993;48:171-173)

Pulmonary alveolar microlithiasis is a rare idiopathic disease characterised by microliths in the alveoli, first described by Friedrich in $1856^{1}$ and then by Harbitz in $1918 .^{2}$ O'Neill reported a family with pulmonary alveolar

Table 1 Characteristics of pulmonary alveolar microlithiasis cases in Turkey

\begin{tabular}{|c|c|c|c|c|}
\hline Reference & $\begin{array}{l}\text { No of } \\
\text { cases }\end{array}$ & $\begin{array}{l}\text { Age (y) } \\
\text { and sex }\end{array}$ & $\begin{array}{l}\text { Family } \\
\text { history }\end{array}$ & $\begin{array}{l}\text { Diagnostic } \\
\text { procedure }\end{array}$ \\
\hline Eber $^{824}$ & 1 & $20 M$ & - & OLB \\
\hline Tezok $^{9}$ & 1 & $28 \mathrm{M}$ & - & CNB \\
\hline Alpaslan ${ }^{10}$ & 1 & $20 M$ & - & CNB \\
\hline$\tilde{U}^{\prime} r^{11}$ & 1 & $16 \mathrm{M}$ & - & CNB \\
\hline Vidinel $^{1213}$ & 3 & $24 \mathrm{~F}, 30 \mathrm{~F}, 42 \mathrm{M}$ &,,++- & $\mathrm{XR}, \mathrm{CNB}, \mathrm{OLB}$ \\
\hline Gerelioglu $^{14}$ & 1 & $21 \mathrm{M}$ & - & OLB \\
\hline Özdogan'15 & 1 & $22 M$ & NA & OLB \\
\hline$K^{2} a_{a s u}^{16}$ & 1 & $18 \mathrm{~F}$ & - & CNB \\
\hline Özhan ${ }^{17}$ & $i$ & $38 \mathrm{~F}$ & - & CNB \\
\hline Yücel' 1824 & 1 & $21 \mathrm{M}$ & NA & OLB \\
\hline Cakirca'192024 & 1 & $33 \mathrm{M}$ & - & CNB \\
\hline Artvinli $i^{21}$ & 1 & $20 \mathrm{M}$ & - & OLB \\
\hline Enacar $^{2223}$ & 6 & $10 \mathrm{~F}, 12 \mathrm{~F}, 15 \mathrm{M}$ &,,+++ & $\mathrm{XR}, \mathrm{XR}, \mathrm{XR}$ \\
\hline Hacihanefioglu ${ }^{24}$ & 4 & $\begin{array}{l}20 \mathrm{M}, 21 \mathrm{M}, 40 \mathrm{M} \\
41 \mathrm{M}\end{array}$ & $\begin{array}{l}\mathrm{NA}, \mathrm{NA}, \mathrm{NA} \\
\mathrm{NA}\end{array}$ & $\begin{array}{l}\text { OLB, XR, OLB } \\
\text { CNB }\end{array}$ \\
\hline Akcan $^{25}$ & 1 & $34 \mathrm{~F}$ & NA & OLB \\
\hline Kocyigit $^{26}$ & 3 & $40 \mathrm{~F}, 44 \mathrm{~F}, 50 \mathrm{M}$ &,,-++ & OLB, OLB, OLB \\
\hline Yenel $^{27}$ & 2 & $28 \mathrm{~F}, 38 \mathrm{M}$ &,++ & OLB, OLB \\
\hline Kiliçaslan ${ }^{28}$ & 2 & $20 \mathrm{M}, 23 \mathrm{M}$ & NA, NA & CNB, BAL \\
\hline $\operatorname{Dogan}^{29}$ & 2 & $21 \mathrm{M}, 26 \mathrm{M}$ & $\mathrm{NA}, \mathrm{NA}$ & OLB, OLB \\
\hline Balkanli30 $^{30}$ & 1 & $68 \mathrm{M}$ & - & BAL \\
\hline Türktas ${ }^{31}$ & 1 & $29 \mathrm{M}$ & NA & $\mathrm{XR}$ \\
\hline Öztaskent ${ }^{32}$ & 1 & $35 \mathrm{M}$ & - & $\mathrm{XR}$ \\
\hline $\mathrm{Kanra}^{33}$ & 3 & $4 \mathrm{M}, 34 \mathrm{~F}, 20 \mathrm{M}$ &,,+++ & $\mathrm{XR}, \mathrm{OLB}, \mathrm{XR}$ \\
\hline Celikel $^{34}$ & 1 & $40 \mathrm{~F}$ & - & BAL, TBB \\
\hline Yüksel ${ }^{35}$ & 2 & $? \mathrm{M}, 35 \mathrm{~F}$ &,++ & OLB, XR \\
\hline Camsari ${ }^{36}$ & 1 & $19 \mathrm{M}$ & - & BAL, TBB \\
\hline Albayrak ${ }^{37}$ & 1 & $8 M$ & - & OLB \\
\hline $\mathrm{Emri}^{38}$ & 1 & $44 \mathrm{~F}$ & - & OLB \\
\hline $\mathrm{Hazar}^{39}$ & 4 & $30 \mathrm{M}, 46 \mathrm{M}, 17 \mathrm{~F}$ &,,+-+ & OLB, OLB, OLB \\
\hline$U_{c ̧ a n}^{40}$ & 1 & $21 \mathrm{M}$ & - & $\begin{array}{l}\text { OLB } \\
\text { OLB }\end{array}$ \\
\hline Kamali $^{41}$ & 1 & $35 \mathrm{M}$ & NA & OLB \\
\hline
\end{tabular}

OLB - open lung biopsy; CNB - cutting needle biopsy; XR-chest radiograph; TBBtransbronchial biopsy; BAL—bronchoalveolar lavage; NA—unreported. microlithiasis in 1967 and noted that the total number of recorded cases was $70.3^{34}$ Subsequently the number of published cases has risen to $173 . .^{5-7}$ The first Turkish case was reported in 1962, and the total number of Turkish cases reached 52 this year. ${ }^{8}$ As none of the Turkish cases, however, were included in any previous series we reviewed them and summarise their features here..$^{3467}$

\section{Cases}

In all there were 34 male and 18 female patients with a mean age of 27.3 (SD 12) (range 4-68 years-see table 1). Ten of the 52 patients were symptomless but 35,20 , and five complained of dyspnoea, cough, and chest pain respectively. Physical examination revealed dullness and rales in 22 , but no physical findings were noted in 22 of the patients. Cyanosis was noted in seven cases, clubbing in 12, and hepatomegaly in eight. Pectus excavatum and hypertrophic pulmonary osteoarthropathy were additional findings in two subjects. ${ }^{30} 38$ The patients were from all the geographical regions of Turkey, though birthplaces were determined in only 23 cases. $^{922} 2326$

A family history was noted in 19 of the 39 patients. All the familial cases were siblings except for three who had a maternal auntnephew relationship. No family history was available in a quarter of the cases. Ten of the patients with a family history were female.

Nineteen of the patients had evidence of the disease on chest radiographs taken a mean of 3.9 years before the definitive diagnosis. All the radiographs showed the "sandstorm" appearances typical of pulmonary alveolar microlithiasis (figure). The initial diagnoses were sarcoidosis in one case, miliary tuberculosis in 13 cases and unknown in five. Only two with an initial diagnosis of miliary tuberculosis had acid fast bacilli in their sputum.

Although all of the 52 patients had a chest radiograph typical of pulmonary alveolar microlithiasis one patient also had bilateral apical pneumothoraces. ${ }^{9}$ Bilateral diffuse calcification, pleural calcification, emphysematous bullae, and blebs were found in five other patients, who were examined by computed tomography. ${ }^{34} 36384041$ Bone scintigraphy was also performed in seven patients and six had uptake of gallium in the lungs. Respiratory function tests were performed in 25 of the cases. The findings were normal in eight and the others all had a restrictive pattern. Arterial blood gas analysis in 15 patients 


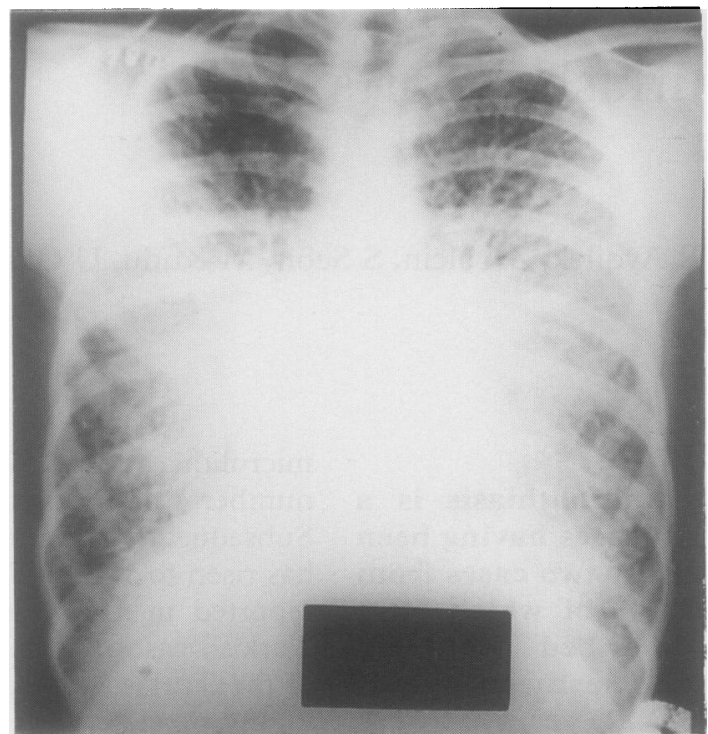

Chest radiograph showing typical sandstorm appearances of pulmonary alveolar microlithiasis

showed no hypoxaemia.

The diagnosis was made by open lung biopsy in 27 of the cases and by cutting needle biopsy, bronchoalveolar lavage, and transbronchial biopsy in nine, four, and four respectively. Radiological findings alone were considered to be sufficient in 12. Bronchoalveolar lavage fluid showed microliths in four of six patients, and transbronchial biopsy provided adequate material for histological examination in two of three patients. ${ }^{28} 3034-3640$

\section{Discussion}

The mean age of our group was similar to that in the cases overall. Nine of our 52 patients were below the age of 18 (table 2). ${ }^{4243}$ The geographical distribution of the patients in Turkey was heterogeneous. Although pulmonary alveolar microlithiasis has been reported from all over the world, 52 $(23 \%)$ of the total of 225 cases now reported come from Turkey. ${ }^{36745}$ In addition, some of the patients reported from foreign countries were ethnic Turks. We therefore believe that pulmonary alveolar microlithiasis is more prevalent among Turkish people. ${ }^{46}{ }^{47}$ Some of the patients reported from other countries had been exposed to certain dusts. None of our patients had an obvious history of such exposure..$^{5-7} 4849$

This review reports 52 cases of pulmonary alveolar microlithiasis from Turkey, 49 of which have previously been described only in

Table 2 Age and sex distribution, presence of family history, and symptoms in patients reported worldwide and in our series

\begin{tabular}{llllll}
\hline Reference & $\begin{array}{l}\text { No of } \\
\text { patients }\end{array}$ & $\begin{array}{l}\text { Mean } \\
\text { age }(y)\end{array}$ & $\begin{array}{l}\text { Male } \\
(\%)\end{array}$ & $\begin{array}{l}\text { Family } \\
\text { history (\%) }\end{array}$ & $\begin{array}{l}\text { Symptomless } \\
(\%)\end{array}$ \\
\hline Sosman & & & & \\
O'Neill $^{4+}$ & 45 & $31-50$ & 46 & 56 & 70 \\
Kino $^{43}$ & 27 & $30-50$ & 50 & 38 & - \\
Prakash $^{6}$ & 51 & $5-9$ & - & 61 & - \\
Mascie-Taylor $^{45}$ & 8 & 23 & 62 & 0 & 62 \\
Volle $^{46}$ & 71 & 32 & 49 & - & 87 \\
Our series & 40 & - & 57 & 52 & - \\
\hline
\end{tabular}

Turkish publications. Where family historie's were available nearly half were positive for the disease, confirming previous reports that pulmonary alveolar microlithiasis may be a familial disease and suggesting that the gene is most common in Turkey. ${ }^{3-5} 3743444750$

Friedrich N. Corpora amylacea in den Lungen. Arch Pathol Anat 1856;9:613-8.

2 Harbitz F. Extensive calcifications of the lungs as distinct disease. Arch Intern Med 1918;21:139-46.

3 Sosman MC, Dodd GD, Jones DW, Pillmore GU. The familial occurrence of pulmonary alveolar microlithiasis. AfR 1957;77:947-1012.

4 O'Neill RP, Cohn JE, Pellegrino ED. Pulmonary alveolar microlithiasis, a family study. Ann Intern Med 1967;67: 957-67.

5 Vidinel I, Tellioglu E. Pulmoner alveolar mikrolityazis Tüberküloz ve Toraks 1969;17:36-53.

6 Prakash UB, Barham SS, Rosenow EC, Brown ML, Payne WS. Pulmonary alveolar microlithiasis. Mayo Clin Proc 1983;58:290-300.

7 Fraser RG, Paré JAP, Paré PD, Fraser RS, Genereux GP. Diagnosis of diseases of the chest. Philadelphia: Saunders, 1991:2693-711.

8 Eber N, Sunay M, Uzunhasanoglu R. Pulmoner alveolar mikrolitiazis. Tüberküloz ve Toraks 1962;10:243-50.

9 Tezok F, Balci K, Baris YI, Kurt C. Bir vaka münasebetiyle diffüz pulmoner alveolar mikrolityazis. Tüberküloz ve Toraks 1964;12:463-9.

10 Alpaslan I, Yagan R. Alveolar mikrolitiazis. Tüberküloz ve Toraks 1966;14:463-8.

11 Üner E, Gürses H, Solu S, Menemenli N. Pulmoner alveolar mikrolithiasis. Tüberküloz ve Toraks 1966;14: 469-72.

12 Vidinel I, Estürk Z, Tellioglu E, Önal A. Pulmoner alveolar mikrolityazis. Ege Tip Fak Der 1967;6:399-403.

13 Vidinel I, Tellioglu E. Pulmoner alveolar mikrolityazis. In XIX Milli Türk Tip Kongresi. Istanbul: Celik Cilt, 1968 146-8.

14 Gerelioglu Y, Büyükünal S, Sekban H, Akkaya A. Bir diffüz pulmoner alveolar mikrolitiazis vakasi münasebetiyle. Tüberkuloz ve Toraks 1967;15:123-6.

15 Özdogan N, Aytug Z, Yazgan C. Pulmoner alveolar mikrolithiazis. In: VIII Türk Tüberküloz Kongrest. Ankara:Ongun Kardesler, 1968:388-94.

16 Karasu N, Öger O, Alper D, Özyardimci N. Diffüz pulmoner alveolar mikrolithiazis. $X$ Türk Tüberküloz Kongresi Ankara:Ongun Kardesler, 1971:573-6.

17 Özhan EH, Karincaoglu O. Pulmoner alveolar mikrolityazis vakasi In: $X$ Türk Tüberküloz Kongresi. Ankara:Ongun Kardesler, 1971:577-9.

18 Yücel EN, Isiklar H, Yurdakul S, Özdemir L. Pulmoner alveolar mikrolithiasis. In: $X$ Türk Tüberküloz Kongresi. Ankara:Ongun Kardesler, 1971:580-2.

19 Cakirca R, Ekmekcioglu A, Aksügür H. Pulmoner alveolar mikrolityazis. Tüberküloz ve Toraks 1971;19:296-300.

20 Cakirca R, Ekmekcioglu A, Aksügür H. Pulmoner alveolar mikrolityazis. In: $X$ Türk Tüberküloz Kongresi. Ankara:Ongun Kardesler, 1971:733-8.

21 Artvinli M, Özesmi M, Baris YI. Pulmoner alveolar mikrolityazis. Hacettepe Tip/Cerrahi Bül 1972;5:407-11.

22 Enacar N, Karabiyikoglu G, Ekim N. Alveola mikrolityazis. In: XIII Türk Tüberküloz Kongresi. Istanbul: Ongun Kardesler, 1977:522.

23 Enacar N, Yavuzer S, Sayli BS, Karabiyikoglu G, Ekim N Pulmoner alveolar mikrolityazis. Tüberküloz ve Toraks 1978;26:186-96.

24 Hacihanefioglu U, Uysal V. Alveolar mikrolitiazis (7 olgu üzerine patolojik inceleme). In: III Ulusal Patoloji Kongresi. Izmir:Bilgehan, 1978:462-70.

25 Akcan I, Coskun Y. Pulmoner alveolar mikrolithiazis. Tüberküloz ve Toraks 1982;30:37-9.

26 Kocyigit E, Gazioglu K, Cavdar T, Erbengi T. Ilginc özellikleri olan 3 alveolar mikrolitiazis vakasi. Solunum 1983 8:276-83.

27 Yenel F, Kücükusta AR. Bir akciger mikrolitiazisi olgusu. Cerrahpasa Tip Fak Der 1984;15:133-7.

28 Kilicaslan Z, Kücükusta AR, Öztek I. Tanilari akciger igne biyopsisi ve bronkoalveolar lavajla dogrulanan ik akciger mikrolitiazisi olgusu. Ege Tip Fak Der 1985;24: 1340-8.

29 Dogan R, Baltacioglu T, Dölalan M, Aksoy B. Pulmoner alveolar mikrolitiasis. Tüberküloz ve Toraks 1986;34: $290-4$.

30 Balkanli S, Demir R, Patiroglu T, Özesmi M. Pulmone alveolar mikrolitiazis tanisinda bronkoalveolar lavaj. Tüberküloz ve Toraks 1987;35:212-6.

31 Türktas $H$, Öztürk $C$, Güven $M$, Ugur $P$, Erzen $C$. Pulmonary alveolar microlithiasis with absence of tech netium $99 \mathrm{~m}$ uptake of lungs. Clin Nuclear Med 1988;13:883-5.

32 Öztaskent $\mathrm{R}$, Demircioglu $\mathrm{N}$, Özacar R. Idiopatik pulmoner alveolar mikrolitiazis. Izmir Gögüs Hast Has 
Der 1988;3:64-6.

33 Kanra G, Tanyol E, Göcmen A, et al. Pulmonary alveolar microlithiasis (a case report). Turkish fournal of Pediatrics 1988;30:61-7.

34 Celikel T, Küllü S, Germen N, Bayik M, Oktay A. Confirmation of diagnosis of pulmonary microlithiasis by transbronchial biopsy: a case report. Respir Care 1989;34:989-92.

35 Yüksel M, Öztek I, Yilmaz G, Balkan E. Bir pulmoner alveolar mikrolitiazis olgusu. Türk Patoloji Der 1990;6: 45-9.

36 Camsari G, Kilic U, Cikrikcioglu S, Öztürk I, Ilker O, Hacihanefioglu U. Pulmoner alveolar mikrolitiazis. Türk Patoloji Der 1990;6:7-10.

37 Albayrak D, Gönül S, Tastepe I, Göcmen A. Ayin vakasi. Yeni Tip Der 1990;7:270-3.

38 Emri S, Cöplü L, Selcuk TZ, Sahin AA, Baris YI Hypertrophic pulmonary osteoarthropathy in a patient with pulmonary alveolar microlithiasis. Thorax 1991;46: 145-6.

39 Hazar A, Erbagci A, Caglar T, Yilmaz N, Erem AR. Mikrolitiazis tanisinda sintigrafinin degeri (4 vaka nedeniyle). In: XIX Tüberküloz ve Gögüs Hastaliklari Kongresi. Sivas: Dilek, 1991:304.

40 Ucan ES, Keyf AI, Aydilek R, Yalcin Z, Kudu M, Sebit S, Ok U. 1962-1991 yillari arasinda Türkiye'de tani konulan alveolar mikrolitiasis olgulari. In: Türkiye Solunum Arastirmalari Dernegi XIX Kongresi. Bursa, Istanbul: Nazim Terzioglu, 1991, 46.

41 Kamali Ü, Yilmaz U, Utkaner G, Günel Ö, Budunelli T Pulmoner alveolar mikrolitiaziste bilgisayarli tomografik ve patolojik bulgular (bir olgu nedeniyle). In: Türkiye Solunum Arastirmalari Dernegi XIX Kongresi. Bursa, Istanbul: Nazim Terzioglu, 1991, 46.

42 Thurairajasinam S, Dharmasena BD, Kasthuriratna $T$. Pulmonary alveolar microlithiasis. Australias Radiol 1975;19:175-80.

43 Kino T, Kohara Y, Tsuji S. Pulmonary alveolar microlithiasis: a report of 2 young sisters. Am Rev Respir Dis 1972;105: 105-10.

44 O'Neill RP, Cohen JE, Pellegrino ED. Pulmonary alveolar microlithiasis a family study. Ann Intern Med 1967;67:957-67.

45 Mascie-Taylor BH, Wardman AG, Madden CA, Page RL. A case of alveolar microlithiasis:observation over 22 years and recovery of material by lavage. Thorax 1985;40:952-3.

46 Volle E, Kaufmann HJ. Pulmonary alveolar microlithiasis in pediatric patients:review of the world literature and two new observations. Pediatr Radiol 1987;17:439-42.

47 Barnard NJ, Crocker PR, Blainey AD, Davies RJ, Ell SR Levison DA. Pulmonary alveolar microlithiasis: a new approach. Histopathology 1987;11:639-45.

48 Nouh MS. Is the desert lung syndrome (non occupational dust pneumoconiosis) a variant of pulmonary alveolar microlithiasis? Respiration 1989;55:122-6.

49 Chinachoti N, Tangchai P. Pulmonary alveolar microlithiasis associated with the inhalation of snuff in Thailand Dis Chest 1957;32:687-9.

50 Garty I, Giladi N, Flatua E. Bone scintigraphy in two siblings with pulmonary alveolar microlithiasis. $\mathrm{Br} \mathcal{f}$ Radiol $1985 ; 58: 763-6$ 